\title{
HISTÓRIA, SENTIDO E TOTALIDADE
}

\author{
NOVA HISTÓRIA EM PERSPECTIVA. \\ Novais, Fernando A. e Silva, Rogerio Forastieri da (orgs.).São Paulo: Cosac Naify, 2011.
}

MANOLO FLORENTINO

Certa vez, em meio a uma reunião científica, foi sugerida a um alto gestor público a extinção dos cursos de mestrado no Brasil. A ideia partiu de um colega da área tecnológica, físico ou químico, não recordo bem. "Para que mestrados? É pura perda de tempo! Deveríamos selecionar nossos alunos diretamente para o doutorado!", argumentou incisivo o colega. A resposta não tardou. $\mathrm{O}$ alto funcionário contestou na lata que, com as devidas exceções, as graduações brasileiras são muito ruins. Ao que, acrescentou, as pós-graduações do país eram legalmente soberanas para tornar obrigatórios ou não os mestrados como etapas da formação de seus alunos.

Ponto para o burocrata!

Pois a verdade é que, ao menos para o caso de História, os mestrados representam momentos de intenso exercício prévio à obra que se supõe resultará do doutorado. $\mathrm{O}$ motivo? A mais antiga dentre as chamadas ciências sociais, a História é, sobretudo, uma disciplina argumentativa - aspecto em que se sobressai dentre a chamada área de humanidades - , mas fundada na correta escolha e utilização de fontes de tipos diversos. Mais que isso, sua abrangência é enorme, seu objeto é, ao fim e ao cabo, indelimitável, o que por certo lhe imprime um caráter altamente artesanal e subjetivo. Mais claramente: argumentação aplicada ao tempo, à mudança, a partir do manejo de corpos documentais cujo escopo vem aumentando nas últimas décadas em função da imensa diversidade temática que cada vez mais caracteriza o ofício de historiador. É, pois, saudável que, ao menos no campo do saber historiográfico, nossos alunos passem por essa etapa preparatória fundamental encarnada nos cursos de mestrado.

Quando menos por isso é de grande importância para estudantes e especialistas em teorias da História a publicação do primei- 
ro tomo da antologia de fôlego (três volumes no projeto original) organizada pelos professores Fernando Antonio Novais e Rogério Forastieri da Silva. Trata-se de trabalho cujo objetivo explícito é inserir a chamada Nova História na história geral da historiografia, enquadrando-a analiticamente em um tempo, em uma conjuntura. Afinal, como alertam Novais e Forastieri na longa e densa introdução à antologia, lenta e imperceptivelmente também a Nova História vai se tornando história.

A estrutura do primeiro volume de Nova História em perspectiva está centrada na apresentação de propostas e desdobramentos. Por propostas entenda-se trazer ao público novas traduções dos manifestos axiais dos nomes mais importantes de cada uma das três fases dos Annales. Daí os textos clássicos de Lucien Febvre, expoente da primeira fase, caracterizada pelo diálogo mais intenso entre a História e, sobretudo, a Sociologia; de Fernand Braudel, catalisador da segunda etapa, quando a interação entre a História e a Economia predominava; e, por fim, os lineamentos apresentados por Jacques Le Goff e Pierre Nora, que na década de 1970 impuseram novos rumos, marcados sobretudo pela maior abertura dos historiadores à Antropologia (ou, como querem Novais e Forastieri, sobretudo com a Etnografia) — a fase da Nova História propriamente dita.

Seguem-se os desdobramentos da avassaladora velocidade com que a Nova História se impôs nos meios acadêmicos ocidentais, contemplados neste primeiro volume da antologia pelas análises de André Burguière, Carlo Ginzburg, Emmanuel Le Roy Ladurie, Hayden White, Joyce Appleby, Lynn Hunt, Margaret Jacob, Massimo Mastrogregori, Maurice Aymard, Michel Vovelle, Natalie Zemon Davis, Philippe Ariès, Pierre Chaunu e Stuart Clark. Fecha o volume o texto de James Harvey Robinson, verdadeiro achado arqueológico, publicado originalmente em 1912 sob o sugestivo e antecipatório título de "A nova história".

O que está em jogo aqui é, a partir de textos seminais, contribuir para o entendimento de como, na perspectiva dos organizadores da antologia, em pouco mais de quatro décadas os sucessivos grupos de profissionais agregados ao redor dos Annales acabaram, não sem profundas descontinuidades, por contribuir para instaurar um cenário historiográfico marcado pela extrema pulverização temática e - com as devidas exceções - por uma "pobreza teórica verdadeiramente capuchinha", nas palavras de Novais e Forastieri.

É evidente, pois, a natureza crítica da longa introdução escrita pelos organizadores à Nova História inaugurada por Le Goff e Nora a partir do lançamento dos três volumes do hoje clássico Faire de l' histoire ${ }^{1}$. Os argumentos apresentados são eruditos, elegantes e fundados em uma [1] Faire de l'histoire. Paris: Gallimard, 1974. lógica ferrenha. 
De início nos é mostrado didaticamente o que vem a ser o fundamento da história-discurso, que corresponde à necessidade da criação da memória social. É estabelecida então a diferença entre a narrativa mítica, própria da constituição da memória coletiva entre os primitivos, e a narrativa histórica propriamente dita, ancorada, ao contrário da primeira, na temporalidade. Como diria certo filósofo, a história-discurso da civilização funda-se na necessária simbolização do homem no tempo.

A anterioridade da História em relação às Ciências Sociais demanda, logicamente, levar em conta o impacto do surgimento destas últimas sobre a História, e não o contrário. Nesse sentido, o século XIX é muito bem localizado pelos organizadores como representando o ponto de inflexão na história do discurso historiográfico, instaurando a forma propriamente moderna de fazer História a partir do diálogo com as Ciências Sociais nascentes. Com uma importante diferença: enquanto as Ciências Sociais sacrificam a totalidade pela conceitualização, a História faz o inverso, sacrifica a conceitualização pela totalidade. Pela simples razão de que o historiador visa explicar para reconstituir um passado necessariamente total — ainda que se foque tal ou qual de seus aspectos - enquanto o cientista social visa reconstituir para explicar.

É a partir desses pressupostos que Novais e Forastieri se posicionam criticamente em relação à terceira fase dos Annales, a da chamada Nova História. Em primeiro lugar, reconhecem que ela conforma um desdobramento das fases anteriores, na medida em que mantém, em termos gerais, o princípio básico de interlocução com as Ciências Sociais. A ruptura, entretanto, a caracteriza quando se detecta a diminuição desse diálogo e a afirmação de certa tendência à desconceitualização - dialoga-se muito mais com a Etnologia do que com a Antropologia, segundo os organizadores. À desconceitualização sucede uma imensa pulverização temática (a "História em migalhas" da qual fala François Dosse) e, pior, a descaracterização da natureza necessariamente total da história, dado que nenhum acontecimento pertence exclusivamente a uma única esfera do existir. Detalhe, bem explicitado por Novais e Forastieri: não se deve confundir esferas da existência (economia, política etc.) com níveis de realidade (estrutura, conjuntura etc.) - toda esfera da existência comporta necessariamente os vários níveis de realidade.

Em termos gerais, estou de pleno acordo com os organizadores deste primeirovolume de Nova História em perspectiva.Observando melhor o perfil de grande parte da produção historiográfica recente, é fácil capturar nele uma enorme gama de ceticismo - corolário do relativismo-,e mesmo de cinismo e niilismo. Mas lembro aqui ser necessário nunca deixar de duvidar. Da importância política da dúvida e do ceti- 
cismo que sempre marcaram a civilização ocidental contemporânea discorrem muito bem Joyce Appleby, Lynn Hunt e Margareth Jacob, na "Introdução a Telling the Truth about History", presente na antologia de Novais e Forastieri.

Mesmo reconhecendo os traços gerais desenhados por Novais e Forastieri, no entanto, insisto no que há de extremamente positivo na crítica ao consagrado, seja ele estabelecido pela tradição ou pelo mercado. No mínimo porque a iconoclastia ou o simples exercício legitimado do espírito de porco abrem campo para todas as formas de expressões artísticas, historiográficas ou teóricas possíveis, inclusive para a apaixonada defesa que Novais e Forastieri fazem do marxismo, na segunda parte de sua introdução. Da importância criadora dos momentos de maior peso do ceticismo na cultura ocidental falam, por exemplo, no campo da literatura, os grandes nomes da ficção norte-americana entre 1920 e 1945 - Scott Fitzgerald, John Dos Passos e Ernest Hemingway, apenas para ficar em alguns dos mais conhecidos.

Por que os cito em um contexto no qual a discussão sobre a natureza na Nova História é o centro? Pelo simples fato de que, com todos os seus problemas, consigo capturar nesse movimento historiográfico a expressão da radicalização do conflito entre a sociedade e o indivíduo, este definitivamente sufocado pelas teorias totalizantes em todos os campos das Humanidades até as décadas de 1970 e 1980 (a longa censura não declarada à obra de Norbert Elias é disso apenas um exemplo). Há no movimento, pois, mais do que desvios em relação às modernas regras que definem o ofício do historiador. Há nele um grito pela localização do sujeito individual na História e a firme decisão de resgatar a tolerância e a diversidade como traços constitutivos da moderna civilização.

MANOLO FLORENTINO é professor do Instituto de História da UFRJ. 